University of Michigan Law School

University of Michigan Law School Scholarship Repository

Other Publications

Faculty Scholarship

2003

\title{
Should Congress Repeal Securities Class Action Reform?
}

Adam C. Pritchard

University of Michigan Law School, acplaw@umich.edu

Available at: https://repository.law.umich.edu/other/28

Follow this and additional works at: https://repository.law.umich.edu/other

Part of the Business Organizations Law Commons, Legislation Commons, Litigation Commons, and the Securities Law Commons

\section{Recommended Citation}

Pritchard, Adam C. "Should Congress Repeal Securities Class Action Reform?" Cato Pol'y Analysis no. 471 (2003): 1-17.

This Report is brought to you for free and open access by the Faculty Scholarship at University of Michigan Law School Scholarship Repository. It has been accepted for inclusion in Other Publications by an authorized administrator of University of Michigan Law School Scholarship Repository. For more information, please contact mlaw.repository@umich.edu. 


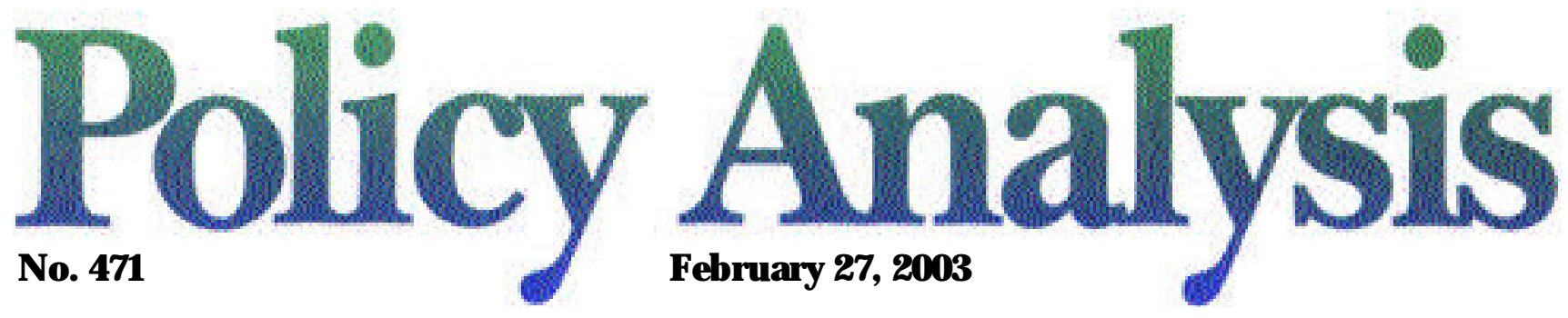

\title{
Should Congress R epeal Securities Class Action R eform?
}

\author{
by Adam C. Pritchard
}

\section{Executive Summary}

The Private Securities Litigation Reform Act of 1995 was designed to curtail class action lawsuits by theplaintiffs' bar. In particular, thehightechnology industry, accountants, and investment bankers thought that they had been unjustly victimized by class action lawsuits based on littlemorethan declines in a company's stock price. Prior to 1995 , the plaintiffs' bar had free rein to use the discovery process to troll for evidence to support its claims. Moreover, the high costs of litigation were a powerful weapon with which to coerce companies to settle claims.

Theplaintiffs' bar and its allies in Congress have called for a repeal or modification of the PSLRA. This paper evaluates the operation of class action lawsuits beforeand after theact. Thehard evidence does not support repealing the PSLRA. In fact, securities class actions are being filed at a record pace. And although a higher percentage of these lawsuits is being dismissed now than beforetheact, theones that survivelead to larger settlements.

The PSLRA raised the standard required before plaintiffs' attorneys could drag a defendant compa ny through the expense of discovery. The lawsuits that meet this higher standard are likely to be less frivolous and are consequently worth more in settlement negotiations. The combination of higher settlements and a smaller percentage of such cases getting to trial suggests that the class action lawsuits under thePSLRA are doing a more cost-effective job of deterring corporate fraud. This condusion is bolstered by the fact that post-PSLRA complaints have more particularized allegations that are more highly correlated with factors related to fraud. In short, the PSLRA is working well, although not as well as intended, and there do not appear to begrounds to either repeal or significantly amend it. A better coursefor reform would beto change the damages remedy in securities fraud class actions to focus on deterrence. 
The drumbeat for further corporate governance reform is certain to includea call for loosening restrictions on securities class actions.

\section{Introduction}

The enactment of the Private Securities Litigation Reform Act of 1995 was a victory for accountants, securities firms, and the high-technology industry, all of which sought to curtail what they perceived as a torrent of securities fraud class actions. Those groups believed that they had been unjustly victimized by lawsuits alleging "fraud by hindsight," based on little more than a sudden drop in a company's stock price. Despite the vigorous resistance put up by the plaintiffs' class action bar, which saw the law as a threat to their very lucrative livelihoods, proponents succeeded in persuading Congress to override President Bill Clinton's veto of the bill and enact the PSLRA.

Subsequent events have substantially diminished the lobbying clout of the industries that promoted the PSLRA. Arthur Andersen's involvement in the accounting legerdemain at Enron and subsequent criminal convictions have brought disrepute on the accounting industry as a whole. Incriminating e-mails from Merrill Lynch, Credit Suisse First Boston, and Salomon Smith Barney suggest that the stock picks that brokers offer their clients may be little more credible than the pitch of the average used-car salesman. The collapse of the hightech bubble erased $\$ 4.3$ trillion in market capitalization from the $\mathrm{N}$ ational Association of Securities Dealers Automated Quotation System. Each of those developments has left multitudes of angry investors in its wake. As a result, Congress-always attuned to the anguish of angry investors-is a much less hospitable place for accountants, investment bankers, and high-tech entrepreneurs than it was a few years ago.

Not surprisingly, opponents of securities fraud class action reform see an opportunity to roll back the PSLRA. The recent spate of corporate scandals has brought the class action bar to the surface, lured by the prospect of tens of millions of dollars in attorneys' fees. Andersen's criminal convic- tion drove it into bankruptcy, but the remaining Big Four accounting firms, the big investment banks, and numerous high-tech companies face a raft of lawsuits seeking billions of dollars in damages and healthy contingent fees for the plaintiffs' attorneys. That class action windfall is not enough for the class action bar. They see Enron, Worldcom, and the host of lesser scandals that have followed as their great chance to undo the securities litigation reforms that Congress adopted in 1995.

The Enron fiasco, the plaintiffs' lawyers say, shows that the curbs on abusive lawsuits created by the PSLRA givecorporations carte blanche to engage in fraud. Plaintiffs' lawyer William Lerach, dean of the class action bar, labels the PSLRA the "Corporate License to Lie Act." He says that there is "no question that the [PSLRA] emboldened executives to think they could do whatever they wanted." The class action bar's friends in the media havejoined thecall for a rollback of securities litigation reform. The New York Times frets that the PSLRA "may prove to bean obstacle to investors as they try to recover tens of billions of dollars from Enron, which has filed for bankruptcy protection, as well as its auditors, lawyers, bankers, partners and others who may have been involved."

That chorus is being heard in the halls of Congress. Sen. Patrick Leahy (D-Vt.) held hearings last year on the implications of Enron for securities class action reforms. Leahy voted against the PSLRA, he says, because "its special legal protections might lead to future financial scandals. Beginning with Enron, thechickens have comehome to roost." Bills have been introduced in the House and Senate that would repeal critical provisions of securities class action reform. The Sarbanes-Oxley Act of 2002 did not incorporate thoseprovisions, although it did extend the time period for filing fraud claims. But the drumbeat for further corporategovernancereform is certain to includea call for loosening restrictions on securities classactions.

This paper evaluates the wisdom of 
repealing the PSLRA. First, it briefly describes how securities fraud class actions operate. Then it discusses the impetus behind thePSLRA and provides an outline of its principal provisions. The study then surveys the impact of the PSLRA on securities fraud class actions. It also evaluates the proposals to roll back certain provisions of the PSLRA and offers an alternative reform for securities classactionsto enhancetheir deterrence of fraud.

\section{Securities Fraud and Securities Fraud Class Actions}

To understand securities fraud class actions, we first need to understand the market abuse that they are intended to remedy. Securities fraud class actions target misrepresentations that arevery different from what we customarily think of as fraud; the corporations that are held responsible for the damages generally do not benefit from the misrepresentations. As a result, the law of fraud does not quite fit those misrepresentations, thereby creating policy dilemmas with no easy solution.

\section{Some Economics of Fraud}

Why do we worry about corporate fraud? In addition to the obvious moral objection to lying, economic analysis supports strong sanctions for fraud. Most conspicuously, fraud may influence how investors direct their capital. Firms that issue securities tend to disclose more information about themselves in an effort to attract investors. If those disclosures are fraudulent, investors will pay an inflated price for those securities and companies will invest in projects that are not cost justified. Fraud may also allow compa nies to retain money or other resources that would be better deployed elsewhere. Managers who fraudulently inflate their company's stock price may be able to invest in ill-advised empire building instead of paying cash flows as dividends to shareholders. Alternatively, managers may use fraud to keep the firm in business when its assets should be redirected through bankruptcy. The bottom line: if capital markets areinfected by fraud, publicly traded firms will face a higher cost of capital because investors will discount the amount that they are willing to pay for securities to reflect the risk of fraud.

M isrepresentations by corporate managers also hurt the shareholders' ability to monitor the firm's performance and, more specifically, to evaluate the job the firm's managers are doing. Insofar as fraud insulates managers from scrutiny, it also may distort the market for corporate control. Poor managers may be able to discourage hostile acquirers by creating the illusion of strong performance. Deterring corporate misrepresentations thereforecan help makemanagers moreaccountableto shareholders.

The U.S. scheme of securities regulation deploys a variety of countermeasures to discourage fraud. Financial statements are audited by reputableaccounting firms. Audit committees of outside directors provide independent oversight of company disclosures. Rating agencies provide assessments of companies' creditworthiness. Analysts rate the credibility and completeness of companydisdosures. In addition to thosemarket mechanisms, fraud is further deterred by Securities and Exchange Commission enforce ment and criminal prosecution of defrauders by the JusticeDepartment and stateprosecutors.

Class actions promise additional deterrence. In fact, the SEC considers private class actions a "necessary supplement" to its own efforts to police fraud. Class actions, however, promisemorethan added deterrence; they also promise compensation to the victims of fraud. That promise of compensation-and the enormous damages that might be necessary to fulfill that promise-strikes genuine fear into the hearts of corporate executives. Surprisingly, the potential for large damages may underminethe deterrent value of securities fraud class actions, as discussed below.

\section{Securities Fraud Class Actions}

The reason that securities class actions carry such large potential damages awards is

\section{If capital markets are infected by fraud, publicly traded firms will face a higher cost of capital because investors will dis- count the amount that they are will- ing to pay for securities to reflect the risk of fraud.}




\section{The wealth trans-} fers caused by fraud on the market overwhelmingly occur between equally innocent investors. the supposed need for compensation, but class actions promise compensation in cases in which it is not justified. Compensation is important in cases in which the corporation has been selling securities through fraud. Compensation corrects the distortion caused by fraud in two ways. First, requiring compensation to the victim discourages the corporation from committing the fraud. Second, compensation discourages investors from expending resources trying to avoid fraud. Expenditures by both the perpetrator and the victim of fraud area social waste, so compensation makes sense in that context. ${ }^{4}$ The federal securities laws encourage such fraud suits by providing a very generous standard for recovery, but despite that encouragement, claims asserting a misrepresenta tion made by a company in connection with an offering of securities makeup onlya small percentage of securities class actions. ${ }^{5}$

The overwhelming majority of securities fraud class actions havelittle effect on capital allocation because the corporations sued are not selling securities. In the typical securities fraud class action, plaintiffs' attorneys sue the corporation and its officers under Rule 10b-5 of the Securities Exchange Act ${ }^{6}$ for alleged misrepresentations regarding the company's operations, financial performance, or future prospects that inflate the price of the company's stock in secondary trading markets such as the N ew York Stock Exchange or Nasdaq. Because the corporation has not sold securities (and thereby transferred wealth to itself), it has no institutional incentive to spend real resources in executing the fraud.

That type of fraud, commonly referred to as fraud on the market, also differs from what wetypically consider fraud in that there is no net wealth transfer away from investors, at least in the aggregate. Instead, the wealth transfers caused by fraud on themarket overwhelmingly occur between equally innocent investors. For every shareholder who bought at a fraudulently inflated price, another shareholder sold: The buyer's individual loss is offset by the seller's gain. Assuming all traders are ignorant of the fraud, over time they will come out winners as often as losers from fraudulently distorted prices. Therefore, shareholders should have no expected loss from fraud on the market, so they would have no incentive to take precautions against fraud. ${ }^{7}$ They simply need to diversify to protect themselves against the risk of fraud.

Despite the fact that the corporation being sued has not gained from fraud on the market, class action lawsuits allow a full measure of compensation to investors who come out on the losing end of a tradeat a price distorted by misrepresentation. Those investors are entitled to recover from thecorporation their losses due to the corporation managers' misstatements. Given the trading volume in secondary markets, the potential recoverable damages in such suits can bea substantial percentage of thecorporation's total capitalization, easily reaching hundreds of millions of dollars. Occasionally the damages measure goes much higher. Cendant Corporation recently set records by settling a securities fraud class action for close to $\$ 3$ billion. With potential damages in this range, class actions are a big stick to wield against fraud.

Punitive sanctions of that sort are only appropriate, however, when they closely correspond to the actual incidence of fraud. Securities fraud class actions fall far short of that ideal. Distinguishing fraud from mere business reversals is difficult. The external observer may not know whether a drop in a company's stock price is dueto a prior intentional misstatement about its prospectsthat is, fraud-or a result of risky business decisions that did not pan out-that is, mis judgment or bad luck. Unableto distinguish the two, plaintiffs' lawyers must rely on limited publicly available indicia (eg., SEC filings and press releases from the company, evidence of insider trading by the managers alleged to beresponsiblefor the fraud) when deciding whom to sue. Thus, a substantial drop in stock price following news that contradicts a previous optimistic statement may well lead to a lawsuit. 
That leaves courts with the difficult task of sorting out the cases with potential merit from the strike suits. The principal tool that courts use in that task is the scienter standard required to establish fraud. The scienter standard-the defendants' knowledge that their statements werefalsewhen made, or the defendants' reckless disregard for the truthis notoriously amorphous. It is somewhat morestringent than negligence (would a rea sonable person have made the statement?), but even in theory it is difficult to say how much more stringent, and it is nearly impos sibleto specify in practice. Courts and jurors, with hindsight, may have difficulty distinguishing knowingly false statements from unfortunate business decisions. Both createa risk of liability and, thus, provide a basis for filing suit. An uncertain standard for liability makes filing a diverse portfolio of cases a rea sonablestrategy for plaintiffs' lawyers. Sueall of the plausible candidates and let the courts sort them out.

Filing numerous cases is not only reasonable but also profitable for plaintiffs' attorneys because of the incentives that defendants face. If plaintiffs can withstand a motion to dismiss, defendants generally will find settlement cheaper than litigating to a jury verdict, even if the defendants believe that a jury would share their view of thefacts. Any caseplausible enough to get past a judge may be worth settling if only to avoid the costs of discovery and attorneys' fees, which can be enormous in these cases. Securities fraud class actions are expensive to defend because the focus of litigation will often be scienter, that is the extent and timing of the defendants' knowledge. The most helpful source for uncovering that information will be the documents in the company's possession. Producing all documents relevant to theknowledge of senior executives over many months or even years can bea massive undertaking for a corporate defendant. Having produced the documents, the company can then anticipate a seemingly endless series of depositions, as plaintiffs' counsel seeks to determine whether the executives' recollec- tions square with the documents. The cost in lost productivity may dwarf the expense of attorneys' fees and other direct litigation costs. Beyond the cost in executives' time, the mere existence of the class action may dis rupt relationships with suppliers and customers, who will be understandably leery of dealing with a business accused of fraud. For those reasons, the Supreme Court has recognized that securities fraud suits pose "the threat of extensive discovery and disruption of normal business activities."

Putting to one side the costs of litigation, the enormous potential damages also make settlement an attractiveoption for thecompa ny, even when it thinks it has a good prospect of prevailing at trial. The math is straightforward: A 10 percent chance of a $\$ 250$ million judgment means that a settlement for $\$ 24.9$ million makes sense. The combination of the cost of litigating securities class actions and the potential for enormous judgments means that even weak cases may produce a settlement if they are not dismissed before trial. If both weak and strong cases lead to settlements, the deterrent effect of class actions is diluted because innocent and wrongful conduct both lead to sanctions.

Deterrence is further diluted by the settlement dynamic in securities fraud class actions. ${ }^{10}$ As discussed above, corporations typically do not benefit from fraud on the market because they are not selling securities at the time of thefraud. Who, then, benefits? The answer is the corporate managers who disguised poor corporate performance in an attempt to keep their jobs, or who inflated profits so that they could reach targets for incentive compensation or bring their stock options into the money. ${ }^{11}$ Of course those objectives benefit the managers rather than theshareholders of thecorporation. They are examples of managers' taking advantage of their positions.

N otwithstanding the self-dealing implicit in such fraud, the corporate officers who actually make the misrepresentations almost never contribute to the settlement of class actions. The dirty secret of securities fraud

An uncertain
standard for lia
bility makes fil-
ing a diverse
portfolio of cases
a reasonable
strategy for plain-
tiffs' lawyers. Sue
all of the plausi-
ble candidates
and let the courts
sort them out.




\section{If both weak and strong cases lead \\ The Private Securities Litigation Reform Act} to settlements, the deterrent effect of class actions is diluted because innocent and wrongful conduct both lead to sanctions. class actions is that the company and its insurers pay to settle the claims even though the officers are the ones responsible for the fraud. As a result, shareholders who have already been harmed by the loss of the corporation's credibility due to the managers' malfeasance also get stuck with the bill for the class action in the form of the cost of settlement, payment of attorneys' fees, and higher directors' and officers' insurance premiums. Securities fraud class actions are largely a device for shifting money between groups of shareholders, with thelawyers taking a healthy slice as compensation for arranging the transfer.

The legislative history of the PSLRA reflects the legislation's two central goals. The first is to rein in the class action bar so that defrauded investors receive more compensation. Given the relative unimportance of compensation, that goal might be seen as largely a pretext for Congress to launch a partisan attack on the plaintiffs' bar. The second, more important goal is to discourage frivolous litigation. That promises to enhance deterrence by more precisely targeting the sanctions imposed by securities class actions. The PSLRA includes numerous provisions intended to achievethose goals.

\section{Reining in the Plaintiffs' Bar}

Congress concluded after extensive hearings that plaintiffs' lawyers were acting for their own benefit instead of faithfully representing investors. Plaintiffs' lawyers weretaking an exorbitant share of settlements for themselves, leaving defrauded investors with only a fraction of the damages that they had suffered. Plaintiffs' lawyers could charge handsome fees because the nominal plaintiffs in securities fraud class actions weretypically "100-share plaintiffs." According to the Report on PSLRA of the Committee on Banking, Housing and Urban Affairs of the

\section{U.S. Senate:}

Under the current system, the initia tive for filing 10b-5 suits comes almost entirely from the lawyers, not from genuine investors. Lawyers typically rely on repeat, or "professional," plaintiffs who, because they own a token number of shares in many companies, regularly lend their names to lawsuits. Even worse, investors in the class usually have great difficulty exercising any meaningful direction over the case brought on their behalf. The lawyers can decide when to sue and when to settle, based largely on their own financial interests, not the interests of their purported clients. ${ }^{12}$

The Senatereport further charged that plaintiffs' lawyers recruited malleable "professional plaintiffs" through "the payment of a 'bonus' far in excess of their share of any recovery."

Congress also found abuses in the settle ment process. Plaintiffs' lawyers typically received a third of the settlement, with the plaintiffs often receiving pennies on the dollar for their claims. M embers of the plaintiff class often received inadequate notice of the terms of the settlement. Congress also criticized the courts, charging that judges rubberstamped abusive settlements on "thepremise that a bad settlement is almost al ways better than a good trial."13

To correct those abuses, Congress enacted a series of provisions intended to "empower investors so that they-not their lawyersexercise primary control over private securities litigation." 14 The PSLRA places substantial restrictions on plaintiffs' attorneys in connection with settlements of securities class actions. Most notably, the law limits attorneys' fees to a reasonable percentage of the class recovery. One of the more novel reforms is the PSLRA's lead plaintiff provision. The law requires national publication of a notice advising class members that the 
action has been filed. ${ }^{15}$ The PSLRA then directs the court to appoint a "lead plaintiff" from among class members who seek to act in that capacity. There is a rebuttable presumption that the most suitable plaintiff is the class member or group of members that has the largest financial interest in the relief sought. That presumption is intended to "encourage institutional investors to take a more active role in securities class action lawsuits."16 The act further discourages reliance on the "100-share plaintiff" by prohibiting bonus payments to class representatives and limiting plaintiffs to serving as a class repre sentativeno morethan fivetimes during any threeyear period. N otably, the lead plaintiff selects counsel for the class, subject to court approval. The lawyer who initially filed the action hopes to fill that role, but need not.

\section{Discouraging Frivolous Suits}

Congress's second motivation in passing the PSLRA was that class actions were being filed in a shotgun fashion. Plaintiffs' lawyers were filing suits with "a laundry list of cookiecutter complaints" against companies "within hours or days" of a substantial drop in the company's stock price, according to the Report of the Committee on Commerce of the House of Representatives on the Common SenseLegal Reforms Act of 1995. ${ }^{17}$ Moreover, the Senate report indicated that plaintiffs' lawyers had incentives to "file frivolous lawsuits in order to conduct discovery in the hopes of finding a sustainable claim not alleged in the complaint." ${ }^{\prime 18}$

Congress believed that, in the prePSLRA environment, a substantial number of weak cases settled becausetheunderlying legal merits could not be determined from the complaint alone. Faced with the cost of discovery, defendantsfound that "thepressureto settlebecame enormous." ${ }^{\text {"19 }}$ Even if a company werewilling to bear the expense of litigation, Congress concluded that the company would inevitably settle rather than face a potentially ruinous jury verdict. Theoverall effect was that liability exposure was chilling issuers from making state ments about their businesses:
Private securities class actions under 10b-5 inhibit freeand open communication among management, analysts, and investors. This has caused corporatemanagement to refrain from providing shareholders forward-looking information about companies.... Asa result, investors often receive less, not more, information, which makes investing more risky and increases the cost of raising capital. ${ }^{20}$

Congress also worried that innocent bystanders were being caught in the securities fraud class action crossfire. According to the Senate report, "underwriters, lawyers, accountants, and other professionals are prime targets of abusive securities lawsuits. The deeper the pocket, the greater the likelihood that a marginal party will be named as a defendant in a securities class action." ${ }^{21}$ Congress found in its conference report that the "system of joint and several liability cre ates coercive pressure for entirely innocent parties to settle meritless claims rather than risk exposing themselves to liability for a grossly disproportionate share of the damages in the case."22 Joint and several liability means that a secondary defendant could be left holding the bag if the defendant that engaged in the fraud later became insolvent, a not infrequent occurrence.

Congress attempted to make securities class actions a more precise deterrent for fraud through a series of procedural obsta cles. The first barrier to frivolous class actions is a "safe harbor" provision for projections that are not knowingly false, or that have been qualified by "meaningful cautionary language."23 That makes it very difficult for plaintiffs to bring lawsuits based on predictions about the company's future that have not come true, the archetypal "fraud by hindsight" claim.

The second barrier has a broader scope The PSLRA imposes a rigorous pleading standard, which requires plaintiffsto specifyin their complaint each statement alleged to havebeen misleading and the reasons why the statement is
The PSLRA imposes a rigorous pleading standard, which requires plaintiffs to specify in their complaint each statement alleged to have been misleading and the reasons why the statement is misleading. 


\author{
Plaintiffs' lawyers \\ continue to face \\ no real sanction \\ for sloppy investi- \\ gation before fil- \\ ing suit or fabri- \\ cating "facts" to \\ allegein their \\ complaint.
}

misleading. The pleading standard also requires plaintiffs to state with particularity facts giving riseto a "strong inference" that the defendant acted with "the required state of mind." ${ }^{24}$ Those rules are applied by the judge reviewing the complaint before any discovery has been conducted. Thus, the pleading standard established by thePSLRA makes thecomplaint the critical document in the case-if the plaintiff cannot make out a credible case of fraud when hefiles his suit, he cannot proceed with his daims. Consequently, judges must play a much more significant role in deciding themerits of thelawsuit than they typically do.

Plaintiffs are left without the usual access to discovery to bolster their complaint. All discovery is stayed during the pendency of any motion to dismiss, unless the court finds that discovery is necessary to preserve evidence or prevent undue prejudice $^{25}$ That combination of the pleading standard and the discovery stay is designed to weed out nonmeritorious actions at an earlystage and low cost. Early dismissal with no discovery greatly reduces the expense to corporations forced to defend such suits, thereby limiting the settlement value of weak cases.

The PSLRA further reduces the coercive threat of securities suits by eliminating securities fraud as the basis for a civil racketeering claim under the Racketeer Influenced and Corrupt Organization Act of 1970, with its potential for treble damages. The PSLRA also limits theliability of certain "peripheral" defendants. The act adopts proportionate, rather than joint and several, liability for defendants who are not found to have knowingly violated the securities laws. ${ }^{26}$ That protection is most important for secondary defendants, such as accountants, lawyers, and investment bankers, who may be implicated in fraud by corporate defendants. If those secondary defendants can show that they did not know of thefraud, their liability exposurewill belimited substantially.

\section{Effect of the PSLRA}

The PSLRA has been on the books for six years now, enough time to shed some light on how it has changed corporate disclosure. There is some evidence that the safe harbor for forward-looking statements has encouraged issuers to be more forthcoming. ${ }^{27}$ That begins to correct one of the more perverse results of securities fraud class actions, the chilling of corporate speech caused by fear of lawsuits.

The central goal of the PSLRA, however, was to alter practice in securities fraud class actions, and in that regard the law clearly has had a substantial impact. The process by which lead plaintiffs are selected has become reasonably settled, and after a slow start, institutional investors are now starting to step forward in greater numbers to take charge of securities fraud class actions. Although the lead plaintiff provision still awaits systematic study, there is anecdotal evidence that it is now beginning to have an effect on attorneys' fees. ${ }^{28}$ If that trend continues, the introduction of a vigorous repre sentative for plaintiffs-shareholders promis es to benefit investors by reducing the cost of class actions.

The more fundamental question, however, is whether the PSLRA has discouraged frivolous suits. In that regard, the news is somewhat mixed. Courts have been vigilant in enforcing the PSLRA's discovery stay. On the other hand, courts appear to beignoring the provision of the PSLRA targeted most directly at frivolous actions, the mandatory sanctions inquiry for complaints that have been dismissed. As a result, plaintiffs' lawyers continue to face no real sanction for sloppy investigation before filing suit or fabricating "facts" to allegein their complaint.

Fortunately, the PSLRA's sanctions inquiry requirement is not thelaw's only constraint on frivolous actions. The PSRLA's most important screen for meritless suits is the strong inference pleading standard that requires particularized allegations of fraud in the complaint. There are now hundreds of judicial opinions interpreting the pleading standard, so thereis reason to think that provision is influencing the filing decisions of plaintiffs' lawyers and the settlements that 
they are able to obtain. Here are summaries of the few empirical studies to date focusing on theimpact of the PSLRA on filing and settlement, as well as the stock market's reaction to thelaw.

\section{Filings and Settlements}

The PSLRA has not reduced the number of securities class actions being filed. In fact, the average number of suits is up nearly 25 percent from pre-PSLRA levels, ${ }^{29}$ so it does not appear that the PSLRA has discouraged plaintiffs' lawyers from filing suit. That increase in filings does not necessarily translate to greater liability exposure for corporations. There is also evidence that the PSLRA has resulted in a higher percentage of cases being dismissed. A study by the $\mathrm{National}$ Economics Research Associates reports that the dismissal rate for securities fraud class actions has roughly doubled since the pas sage of the PSLRA, so nearly a quarter of all suits are now dismissed. ${ }^{30}$ If weaker lawsuits are dismissed at an early stage before compa nies must bear the cost of discovery, then companies will bear minimal expense from those suits, although they may still suffer some reputational harm.

The twin findings of more filings and more dismissals are seemingly contradictory. Why would plaintiffs' lawyers wastetimeand effort filing suits that are likely to be dismissed? Plaintiffs' lawyers argue that the upsurge in filings simply reflects a massive expansion in the amount of fraud being committed. The plaintiffs' bar can find support for their position in concerns expressed by theSEC and other policymakers about the quality of financial reporting. The only difference post-PSLRA, say the lawyers, is that meritorious suits are now being dismissed.

An alternativeexplanation for thesurgein filings is that the plaintiffs' lawyers are inca pable of sorting fraud from misjudgment or bad luck on the basis of the information available to them. Consequently, they sue on the basis of bad news that may reflect either. If they can withstand the defendant's inevitable motion to dismiss, they can gain access to discovery of the corporation's internal documents in an attempt to determine whether there has been fraud. A higher dismissal rate means that plaintiffs' lawyers need to file more suits in hopes that a rea sonable number will make it through to dis covery. If plaintiffs' lawyers are simply filing more suits in the hope that a few will "stick," the PSLRA may not haveachieved its goal of discouraging frivolous class actions. But if thosefrivolous actions arequickly dismissed, the costs of defending them are greatly diminished. Moreover, the higher dismissal rate suggests that the sanctions that flow from securities fraud class actions are more precisely targeted-that is, weaker suits are more often dismissed. If only strong claims lead to settlements, class actions are producing more cost-effective deterrence.

Deterrence is determined not only by the precision, but also the magnitude, of sanctions. Studies have found that monetary settlements are higher for post-PSLRA cases, but they are lower when expressed as a percentage of potential damages. ${ }^{31}$ If securities fraud class action settlements now include a higher percentage of meritorious claims (as a result of the higher dismissal rate), then higher absolute sanctions are appropriate. The fact that monetary settlements may bea lower percentage of potential damages is not a cause for concern. Higher stock prices and more trading lead to higher potential damages, so it is no surprise that damages are greater after 1995 because of rising stock prices and increased trading during that time Given that potential damages are unrelated to the social harm stemming from fraud on the market, it is not essential from a deterrence perspective that recoveries correspond to those damages.

The available evidence also shows that suits naming accountants and underwriters haveled to greater settlements than suits that do not name them both before and after the PSLRA was adopted, suggesting that the PSLRA has not exempted secondary defendants from paying damages. It is more difficult to name secondary actors as defendants,

\section{If plaintiffs'} lawyers are simply filing more suits in the hope that a few will "stick," the PSLRA may not have achieved its goal of discouraging frivolous class actions. 
but when theplaintiffs provideevidence that ties those defendants to the fraud, they are being forced to pay.

\section{The Stock Market's Response}

One method of assessing the PSLRA's impact is by measuring the stock market's reaction to the law. That reaction provides important evidence on the effect of the PSLRA because shareholders are the intended beneficiaries of the deterrence produced by securities fraud class actions. Shareholders suffer, however, if firms are subjected to frivolous suits that impose costs but do little to deter fraud. That tradeoff between the costs and benefits of class actions should be reflected in shareholders' valuations of firms subject to the PSLRA.

Two stock market reactions are relevant to an assessment of the PSLRA's effect. The first is investors' reaction to Congress's overrideof President Clinton's veto of thePSLRA. Two studies found that the enactment of the PSLRA was wealth increasing, on average, for shareholders in high-technology firms (a favorite target of the class action bar). ${ }^{32}$ Specifically, there was a significant negative market reaction to the rumors of President Clinton's veto, followed by a significant posi tive reaction to the override. Firms at the highest risk of being sued enjoyed the strongest positive reaction. Those findings suggest that shareholders generally believed that they would benefit from the PSLRA's restrictions on private securities litigation.

The second relevant finding from the stock market came in response to a decision by the U.S. Court of Appeals for the Ninth Circuit. The Ninth Circuit, which encompasses Silicon Valley, surprised many observers with its Silicon Graphics decision interpreting the PSLRA's requirements for pleading a securities fraud complaint. Prior to thePSLRA, theN inth Circuit had theleast stringent requirements for pleading fraud of all circuit courts. The Ninth Circuit's interpretation in Silicon Graphics, by contrast, is the most stringent of any circuit, requiring plaintiffs to allege facts that would show the defendants were "deliberately reckless" in making the misrepresentation that gave rise to the fraud claim. ${ }^{33} \mathrm{~N}$ ot surprisingly, courts that have adopted that more stringent standard are morelikely to dismiss lawsuits. ${ }^{34}$

The tougher pleading standard allows a court to dismiss fraud suits at an early stage if the court deems they lack merit, but it also increases the risk that a court will dismiss meritorious suits. If cases of genuine fraud were dismissed or never filed, deterrence would be undermined. Marilyn Johnson, Karen N elson, and I did a study of the stock market's reaction to the Silicon Graphics decision for a sample of high-technology compa nies. We found a positive market reaction to the decision, particularly for firms headquartered in theN inth Circuit and those at greatest risk of being sued in a securities class action. ${ }^{35}$

Those results relating to the enactment and interpretation of the PSLRA bolster the conclusion that market participants believed that its restrictions on private securities litigation generally benefited shareholders of high-technology firms. That reaction pre sumably reflects an assessment by those participants that the PSLRA discourages the filing of nonmeritorious claims, without unduly chilling meritorious claims and the deterrent benefits that they may produce. That conclusion comes, however, with a caveat: The assessment of investors may have been fueled by popular perceptions and anecdotal evidence. Market participants may not have had the information or expertise to assess whether the PSLRA had its desired effect of reducing nonmeritorious claims.

\section{Do the Merits Matter More?}

Although market reactions are instructive, the more fundamental question is whether the PSLRA has achieved its central goal, the deterrence of frivolous lawsuits. As noted above, the overall number of suits has not declined, despite the barriers to class actions erected by the PSLRA. After a brief initial dip, the number of securities fraud class actions has returned to, and even 
exceeded, its prePSLRA level. On its face, the increase in filings suggests that the PSLRA may have done little to discourage the filing of frivolous suits. It is worth noting in this regard, however, that it appears that a smaller percentage of cases is being filed in the Ninth Circuit subsequent to the Silicon Graphics decision, suggesting that the stringent standard adopted therehas discouraged somesuits. $^{36}$

A second study that I did with Marilyn Johnson and Karen Nelson provides more direct evidence on whether the PSLRA has discouraged frivolous suits. Once again studying a sample of high-tech companies, we found that factors relating to the likelihood of fraud-principally restatements of accounting results and insider trading-play a moreimportant rolein explaining theincidence, thetype of allegations, and theresolution of class actions post-PSLRA. Factors relating to fraud weregenerally insignificant before the passage of the PSLRA. Factors relating to damages (such as share turnover and market capitalization), not surprisingly, have been important in explaining class actions both before and after the passage of the PSLRA. Damages factors, although unlikely to correlate with fraud, will always play a role in determining the incidence of suit because greater potential damages claims correlate with greater attorneys' fees. Nonetheless, the results show a closer rela tion between factors related to fraud and securities class actions after the passage of the PSLRA, suggesting that Congress achieved at least part of its objectivein enacting thelaw.

In sum, the empirical evidence produced to date suggests that the PSLRA has made the plaintiffs' bar work harder for a living. The PSLRA discourages plaintiffs' lawyers from using lawsuits to fish for evidence. Today, complaints are better drafted, with stronger support for allegations of fraud. Marginal cases are more likely to be dis missed and less likely to lead to a settlement. In sum, the PSLRA has madethe merits matter more to attorneys considering a suit.

\section{Should the PSLRA Be Repealed?}

The evidence above suggests that the PSLRA has reduced the costs to corporate issuers of defending meritless class actions and encouraged plaintiffs' lawyers to target their lawsuits more precisely. Despite that evidence, calls for the repeal of securities fraud class action reform have been growing in the wake of revelations of fraud at a number of high-profilecompanies.

\section{Did the PSRLA Cause a Fraud Epidemic?}

The impetus for calls to repeal thePSLRA is easy to understand. A spate of accounting and corporate governance scandals followed shortly after the passage of a law that madeit more difficult to sue for fraud. And it's not just the fraud headlines that support this impulse the number of restatements of accounting results has generally been on the rise $^{37}$ Some use that chronology to imply a causal relation between the PSLRA and corporatefraud.

That logic is based on publicity rather than sound statistical inference. After a flurry of headlines trumpeting corporate wrongdoing, it is easy to be misled by a small number of high-profile cases, but the Enrons and Worldcoms are not representative of America's corporations. The United States has morethan 15,000 public companies, and only a handful of them have been implicated in wrongdoing. Fraud will al ways be with us, and it would be a mistake to conclude from what may be little more than a statistically insignificant blip that we are headed toward a financial apocalypse. The increased number of restatements is also misleading. Many of those restatements are the result of shifts by the SEC in interpreting accounting rules. A company's failure to anticipatea change in the SEC's position does not equate to fraud.

Weshould also remember theother factors in the financial environment that helped lead to the corporate scandals. M ost conspicuous was the public's voracious appetite for any
The Enrons and Worldcoms are not representa tive of America's corporations. TheUnited States has more than 15,000 public companies, and only a handful of them have been implicated in wrongdoing. 


\section{Whatever there-} ative merits of options and cash compensation, there is certainly no reason for Congress to put its fat thumb on the scale in favor of one over the other. business concept, no matter how shaky, that had some connection to the Internet. Companies with actual earnings became passé, rendering quaint guideposts such as price-to-earnings ratios irrelevant. We are more sober now but still reluctant to admit that we were taken in by the hysteria for all things high tech-just likethenow-failed whiz kids who dreamed of a business revolution.

Another ingredient was the popularization of stock options at the expense of more traditional forms of compensation, such as cash. The stock option frenzy of the late 1990s was driven in part by companies with good ideas, but little cash, that needed to attract talented employees. But that frenzy was also driven by an excisetax that Congressimposed on "excessive" executive compensation in 1993-yet another example of the law of unintended consequences. $^{38}$ The excise tax excluded "incentive" compensation, so not surprisingly, compensation consultants found a way to drive a Mack truck through that loophole. Theresult was an enormous spikein theuseof stock options, with a corresponding motivation to keep thoseoptions "in themoney." For theoptionsto belucrative, thecurrent price of the stock had to exceed the exercise price of theoption. And if accounting resultshad to be massaged a little to inflate the stock price, what was the harm? We have now found out what the harm was-a dramatic loss in investor confidence. Stock options area useful component of many compensation packages, helping to align managers' and investors' interests, but they are no panacea. Whatever the relative merits of options and cash compensation, there is certainly no reason for Congress to put its fat thumb on the scale in favor of one over the other.

\section{Proposed Reforms}

A number of bills were introduced in Congress during 2002 aimed at undoing securities class action reform. N ot surprisingly, given Arthur Andersen's rolein the demise of Enron, accountants were the central target. Those bills include proposals to bring back joint and several liability for secondary defendants and restore aiding-and-abetting liability and racketeering liability under RICO for securities violations. ${ }^{39}$ Another proposal would eliminate the discovery stay if auditors were named as defendants, allowing the plaintiffs' attorney immediate access to theaccountants' work papers. ${ }^{40}$

Is diminished liability for secondary defendants a real concern? Hardly. The reputational sanction for complicity in fraud is severe, as Andersen's bankruptcy filing after its conviction for obstruction of justice shows. Professionals such as accountants are in the business of renting their reputation to corporations. Once the accountants lose their reputation for integrity, they havenothing left to sell. The market sanction for mis behavior is swifter and surer than any punishment that Congress is likely to devise.

Moreover, the PSLRA does not let secondary defendants off scot-free. Proportionate liability does not mean that accountants, lawyers, and underwriters are immune from liability. It only means that they are responsi ble only for the incremental harm caused by their participation in the fraud. Prior to the PSLRA, plaintiffs' lawyers routinely went after accountants, lawyers, and underwriters, who under joint and several liability could be forced to pay the entire judgment, even if their culpability for the fraud was slight. Under the PSLRA, defendants who are only tangentially involved in the fraud will not face potentially bankrupting liability.

But secondary defendants who actively participate in the fraud get no such relief. Under the PSLRA, defendants are only entitled to the protection of proportionateliability when they lack knowledge of the fraud. Even then they can be required to pay an additional 50 percent above the damages based on their fault if the issuer is insolvent. Proportionateliability offers no protection at all for secondary defendants if a jury concludes that they were kneedeep in the fraud. Ernst \& Young no doubt took that possibility into account when it paid $\$ 335$ million to settlethelawsuit against it resulting from the accounting scandal at Cendant. Accountants 
must still consider the risk of a securities fraud class action when a client tries to pressure them into acquiescing in a dubious interpretation of accounting principles.

Another proposal relating to accountants would reverse the Supreme Court's 1994 Central Bank decision, which eliminated "aiding-and-abetting" liability for securities fraud. ${ }^{41}$ Congress considered reversing Central Bank when it was debating the PSLRA, but it instead concluded that only the SEC should be authorized to pursue individuals who have facilitated but not perpetrated securities fraud. ${ }^{42} \mathrm{~A}$ bill was introduced to extend that authority to privatelitigants. The argument was that expanded lia bility would encourage accountants and lawyers to be more vigorous "gatekeepers," denying defrauders access to the financial markets. Without audited financial statements and offering documents produced by accountants and lawyers, defrauders would not be ableto sell securities at all.

As noted above, secondary defendants do not enjoy immunity from liability under current law. If they make misrepresentations upon which investors rely (such as certifying false financial statements), secondary defendants can and will beheld liable. Central Bank only excludes liability when secondary defendants have made no false statement themselves. That is hardly a startling principle. The basic purpose of securities law is to protect investors who reasonably rely on information. If theaccountant or lawyer has made no statement, then investors have not relied on that person in making their investment decision. On theother hand, if the secondary defendants have induced reliance by investors, they will be on the hook, as the recent decision by the trial judge in the Enron class action confirmed. ${ }^{43}$

Aiding-and-abetting liability transforms thelaw of fraud from a sanction for misleading people into a sanction for failing to uncover fraud committed by others. That might make sense if wethought it would be proper to transform professionals into quasifraud police. But there are good reasons why audits of public companies are not full-scale investigations for fraud. A forensic audit to uncover fraud requires an enormous investment of time and resources and therefore costs a multiple of the typical charge for an annual audit. A forensic audit is a hugewaste for the overwhelming majority of public companies that are not engaged in fraud. And the cost of training lawyers to uncover fraud would be staggering - the average corporatelawyer is doing well to understand the transactions that she is asked to document, not to mention looking behind them for nefarious purposes. Uncovering fraud requires specialized expertise that can be developed only through extensiveand expensive training.

The balancestruck by the PSRLA is a sensible compromise. The SEC has the authority to pursue secondary defendants with knowledge of the fraud. Because the commission has morefraud to pursuethan it has time or manpower, we can be confident that theagen cy will not abuse its aiding-and-abetting authority. Facing the knowledge standard, the SEC will pursue secondary defendants only when there is clear evidence of wrongdoing. For the plaintiffs' bar, by contrast, aiding-and-abetting authority is one more weapon with which to shake down a settlement from a deep pocket.

The exclusion of securities fraud from RICO's civil provisions was endorsed at the time of enactment even by then-SEC chairman Arthur Levitt, no friend of defrauders. That exclusion prevents plaintiffs' attorneys from using the in terrorem threat of treble damages as a means of coercing settlements from defendants. Given that potential damages are al ready excessive under the damages measure of the securities laws, the added threat of civil RICO served no useful purpose. More important, it is specious to suggest that anyone who is not deterred by the prospect of billions of dollars in damages is going to be deterred by trebling those damages under RICO. Bankrupt is bankrupt.

The proposal to eliminate the discovery stay for auditors' work papers would essential-
The market sanction for misbe havior is swifter and surer than any punishment that Congress is likely to devise. 


Aiding-and-abet-
ting liability
transforms the
law of fraud from
a sanction for
misleading peo-
ple into a sanc-
tion for failing to
uncover fraud
committed by
others.

ly repeal the discovery stay altogether. Access to the work papers, with all of the details that they provideabout a company's business, not only compromises corporate confidentiality, it also ensures that auditors will be routinely named as defendants so that plaintiffs' lawyers can go back to their old practice of using discovery as a "fishing expedition" for fraud. Whether or not the work papers reveal fraud, they will allow the plaintiffs' lawyers to amend their complaint and plead sufficient detail to get past a motion to dismiss. That will bring the coercive threat of discovery against thecompany and its officers to bear in settlement negotiations. The PSLRA's barriers against nuisance suits, which have greatly reduced the expense of defending such actions, would becompletely eroded.

Another bill would repeal the Securities Litigation Uniform Standards Act, ${ }^{44}$ a 1998 supplement to thePSLRA. Plaintiffs' lawyers initially responded to the restrictions that the PSLRA imposes on federal securities class actions by filing their suits in state court, where the PSLRA does not apply. Congress closed that loophole in 1998 by preempting class actions based on state securities fraud law for certain classes of securities. Undoing that preemption would reverse the improve ments in securities fraud class action proce dures that have been produced by the PSLRA.

A final proposal calls for lowering thestandard required for fraud under the securities laws from scienter, which means actual knowledge or at least a reckless disregard for the truth, to negligence, which translates to "would a reasonable person have believed that hewastelling thetruth?" Thenegligencestandard has obvious appeal-We're all reasonable people, aren't we?-but therearegood reasons for using scienter instead. The scienter requirement is the chief bulwark against "fraud by hindsight"-the temptation to conclude that a defendant accused of fraud must have known that the bad thing was going to happen at the time of his statements because the bad thing eventually did happen.

Although it may bedifficult for theaverage juror to believe, it is often true that the chief executive officer and the board did not know that a fraud was being committed. Public corporations cannot al ways manage information flows among multiple divisions and elaborate management hierarchies. The scienter standard counteracts those biases by requiring strong evidence of an intentional misstatement before a defendant can beheld liable for fraud. If there is evidence in corporate documents or from other employees that thedefendant did know thetruth at thetimeof themis statements, thejury is freeto ignorethe defendant's denials of knowledge. Claims by corporate officers that "they didn't know" of the fraud are a risky litigation strategy.

\section{A Better Alternative}

Instead of rolling back securities fraud class action reform, Congress should consider new reforms that would target the deterrent effect of securities fraud class actions where that would do the most good. One of the salutary developments in securities fraud litigation to come out of the recent spate of accounting scandals has been the targeting of corporate officers in fraud suits. Traditionally, class action settlements have not included a contribution from corporate officers individually. Plaintiffs' lawyers forgo that source of recovery because they can reach a settlement much morequickly if they do not insist on a contribution from theindividual defendants. The only reason that officers and directors are named is to improve the plaintiffs' lawyer's bargaining position.

Faced with a substantial number of bankrupt companies with no assets to pursue, however, the class action bar has turned its sights on the individuals who are actually culpable for the fraud. Some of the officers were able to abandon ship with substantial gains by cashing out stock options beforethe collapse. When AI Dunlap, the former CEO of Sunbeam Corporation, recently was forced to contribute to the settlement in the class action arising out of that firm's bankruptcy, it was a "man bites dog" story for people familiar with securities fraud class 
actions. But the Dunlap story could become a trend. Those stock option millions are a tempting target for plaintiffs' lawyers stymied by bankrupt corporate issuers.

Deterrence is maximized by sanctioning the person who is most at fault for the fraud. Accordingly, the pursuit of culpable corporate officers should not be limited to cases involving bankrupt firms. Congress can encourage plaintiffs' lawyers to go after the real wrongdoers in every fraud case by altering the damages remedy for Rule 10b-5 fraud on the market cases. The current rule holds corporations responsiblefor theentireloss of all of the shareholders who paid too much for their shares as a result of fraudulent misrepresentations. But that measure exaggerates the social harm caused by fraud on the market because it fails to account for the gains of equally innocent shareholders who sold at the inflated price. In most cases, the losses and gains will bea wash for shareholders in the aggregate, even though some individual shareholders will have suffered substantial losses.

A better damages rule would focus on deterrence rather than compensation. Instead of making corporations liable for all losses resulting from misstatements, weshould force defendants to disgorge their gains (or expected gains, for those who fail in their scheme) from the fraud. So if a corporation were issuing securities at the time it was distorting the market price of its stock, it would be required to disgorge the amount by which it inflated the price of the securities that it sold to the investors who bought them. In most fraud on themarket cases, however, thecorporation has not benefited from themisrepresentation that is the basis of the class action. Indeed, thecorporation is usually the victim of the fraud. The corporation is victimized when an executive is awarded a bonus that is undeserved because he creates the appearance of having met the target stock price. The corporation is also victimized when a chief executive officer keeps his job for a bit longer because he creates the appearance of adequate performance. The proper remedy in such cases is for the execu- tiveto return the bonus or salary earned from the fraud to the corporation. If the executive benefits from the fraud by cashing out stock options at an inflated price, those profits can be paid over to the corporation. And for egre gious cases, civil sanctions imposed by the SEC and criminal prosecution by the Justice Department will always be available.

The objective here should be to ensure that fraud does not pay. Therecently enacted Sarbanes-Oxley Act makes a beginning toward making executives pay by requiring them to reimburse the corporation for any incentive compensation (as well as profits from any stock sales) if the corporation is required to restate its financial results. ${ }^{45}$ The big money for plaintiffs' attorneys, however, remains in pursuing the corporation and its insurers. If we took away the corporation's exposure when it did not benefit from the fraud, we would substantially increase the attorneys' incentive to pursue the executives responsiblefor the fraud.

\section{Conclusion}

The call to roll back securities litigation reform comes as no surprise in the wake of a series of high-profile scandals at major public corporations and investment banks. The intuitivelink between thePSLRA's barriers to lawsuits and the misbehavior that has unfolded in corporate boardrooms and financial markets is all too easy to make. Unfortunately, public policy is too frequently driven by such intuitions based on the latest headlines rather than hard evidence.

In this case, the hard evidence does not support the call to repeal the PSLRA. Securities fraud class actions are being filed at a record pace ThePLSRA has not discouraged the filing of lawsuits. Although a higher percentage of those suits is being dismissed, the ones that survive lead to larger settlements. That result should come as no surprise because the PSLRA demands stronger evidence from plaintiffs' attorneys before they can drag defendants through the expense of
Deterrence is maximized by sanctioning the person who is most at fault for the fraud. Accordingly, the pursuit of culpa ble corporate officers should not be limited to cases involving bankrupt firms. 


The combination
of higher settle-
ments and a
smaller percent-
age of those cases
getting to trial
suggests that
securities fraud
class actions are
now doing a bet-
ter job of deter-
ring fraud.

defending a securities fraud class action. Cases that meet that tougher standard are worth more in settlement negotiations.

The combination of higher settlements and a smaller percentage of those cases getting to trial suggests that securities fraud dass actions are now doingabetter job of deterring fraud. Current proposals to repeal securities fraud dass actions would give plaintiffs' lawyers another weapon with which to coerce settlements. But the wide net those proposals would cast offers littlein the way of enhanced deterrence Strong sanctions are appropriate for defrauders, but we must ensure that those sanctions are imposed only on culpa ble parties. Honest businesspeople and professionals need to be protected against threats intended solely to generatelarger settlementsand attorneys' fees. Investors are the intended beneficiaries of the deterrence produced by securities fraud dass actions, but they also bear the costs when dass actions get out of control. Investors bear thosecoststhrough higher insurancepremiums for directors' and officers' insurance, as well as higher fees that accountants, lawyers, and investment bankers will chargeif they faceunjustified litigation risk.

The PSLRA struck a balance between the goal of deterrence and the costs that securities fraud class actions impose on investors. The evidence to date suggests that the balance struck was a reasonable one. Congress will not be doing investors a favor if it opens the door to frivolous class action lawsuits and coercive settlements in its frenzy to get tough on corporatewrongdoers.

\section{Notes}

1. Lori Cabro, "I Told You So," CFO 63 (September 2002): 67 (interviewing Lerach).

2. Stephen Labaton, "Enron Scandal Shocks Even Those Who Helped It Along," New York Times, February 3, 2002.

3. Patrick Leahy, chairman, Senate Judiciary Committee, Statement at Senate Hearing on Accountability Issues: Lessons Learned from Enron's Fall, February 6, 2002.

4. Paul G. Mahoney, "Precaution Costs and the
Law of Fraud in Impersonal Markets," Virginia Law Review 78 (1992): 623.

5. Section 11 of the Securities Act, 15 U.S.C.A. $\S$ $77 \mathrm{k}$, makes issuers strictly liable for misstatements in a registration statement for a public offering. From 1999 to 2000, approximately 14 percent of securities litigation cases involved allegations of violations of the 1933 Securities Act that regulates the offering of securities. See PricewaterhouseCoopers, LLP, "2001 Securities Litigation Study," www.10b5.com/2001Securities LitigationStudy.pdf.

\section{17 C.F.R. § 240.10b-5.}

7. There could of course be a decline in share price attributable to greater uncertainty in valuing the company because of the loss of credibility. That decline, however, is likely to be insignificant relative to the price drop from artificially inflated levels when the fraud is revealed.

8. "Cendant Corp. Agrees to Record Payment to Settle All Financial Fraud Allegations," SeauritiesRegulation \& Law Reporter 31 (December 13, 1999): 1618.

9. Blue Chip Stamps v. Manor Drug Stores, 421 U.S. 723, 742-43 (1975).

10. A. C. Pritchard, "Markets as Monitors: A Proposal to Replace Class Actions with Exchanges as Securities Fraud Monitors," Virginia Law Review 85 (1999): 925.

11. A stock option is said to be "in the money" when the exercise or strike price is equal to or greater than the stock price.

12. S. Rep. N o. 104-98, at 6 (1995).

13. H.R. Rep. No. 104-50, at 17 (1995).

14. S. Rep. No. 104-98.

15. The provision is unusual in that Congress based it on a proposal by two law professors. See Elliot J. Weiss and John S. Beckerman, "Let the Money Do the Monitoring: How Institutional Investors Can Reduce Agency Costs in Securities Class Actions," Yale Law Journal 104 (1995): 2053.

16. H.R. Rep. No. 104-50, at 34 (1995).

17. Ibid. at 16, 17.

18. S. Rep. N o. 104-98, at 14.

19. H.R. Rep. N o. 104-50, at 17.

20. S. Rep. No. 104-98, at 5. 
21. Ibid.

22. H.R. Conf. Rep. No. 104-369, at 37-38 (1995).

23. 15 U.S.C.A. § 78u-5(c)(1).

24. 15 U.S.C. A. § 78u-4(b)(1), (2).

25. 15 U.S.C. § 78u-4(b)(3).

26. 15 U.S.C. § 78u-4(g)(2)(B).

27. Marilyn F. Johnson et al., "The Impact of Securities Litigation Reform on the Disclosure of Forward-Looking Information by High Technology Firms," Journal of Accounting Research 39 (2001): 297.

28. For example, the University of California was able to negotiate a fee of less than 10 percent in the litigation against Enron. Maureen Milford, "UC Takes Charge of Enron Suit," N ational Law Journal, M arch 4, 2002, p. A15.

29. Michael A. Perino, "Did the Private Securities Litigation Reform Act Work?" University of I Ilinois Law Review (forthcoming 2003).

30. Todd S. Foster et al., "Trends in Securities Litigation and the Impact of the PSLRA," National Economic Research Associates, 1999, unpublished manuscript in author's files.

31. Laura E. Simmons, "Securities Lawsuits: Settlement Statistics for Post-Reform Act Cases," Cornerstone Research, 1999, unpublished manuscript in author's files; and Mukesh Baja et al., "Securities Class Action Settlements: An Empirical Analysis," Law and Economics Consulting Group, 2000, unpublished manuscript in author's files.

32. Marilyn F. Johnson et al., "Shareholder Wealth Effects of the Private Securities Litigation Reform Act of 1995," Review of Accounting Studies 5 (2000): 217; and D. Katherine Spiess and Paula A. Tkac, "The Private Securities Litigation Reform Act of 1995: The Stock Market Casts Its Vote," Managerial and Decision Economics 18 (1997): 545.

33. In reSilicon GraphicsInc. Sec. Litig., 183 F.3d 970 (9th Cir. 1999).

34. Joseph A. Grundfest and A. C. Pritchard, "Statutes with Multiple Personality Disorders: The
Value of Ambiguity in Statutory Design and Interpretation," Stanford Law Review 54 (2002): 629.

35. M arilyn F. Johnson et al, "In reSilicon Graphics Inc:: Shareholder Wealth Effects Resulting from the Interpretation of the Private Securities Litigation Reform Act's Pleading Standard," Southern California Law Review 73 (2000): 773.

36. Perino.

37. Financial Executives Institute, "Quantitative M easures of the Quality of Financial Reporting," 2001, unpublished manuscript in author's files.

\section{26 U.S.C. § 162.}

39. Aiding-and-abetting liability targets professionals who facilitate fraud committed by others. Racketering liability under theRICO statuteprovides for treble damages for defendants found to have engaged in a pattern of criminal activity. That criminal activity need not have led to a criminal prosecution, nor must it beproved beyond a reasonabledoubt. As a consequence, ordinary business torts can bethe basis for a racketeering claim. The proposal to restore joint and several liability and aiding-and-abetting liability can be found in Sections 12(a) and 14 of the Comprehensivelnvestor Protection Act of 2002 (H.R. 3818) introduced by former representative John LaFalce (D-N.Y.). In the Senate, Sen. Richard Shelby (R-Ala.) introduced thel nvestor Protection Act of 2002 (S. 1933) that contained those same provisions and that would have repealed the Securities Litigation Uniform Standards Act of 1998. RICO liability would have been restored by the Securities Fraud Prevention Act of 2002 (H.R. 3644), introduced by Rep. John Conyers Jr. (D-Mich.).

40. This proposal can befound in Section 12(e) of the Comprehensive Investor Protection Act of 2002.

41. Central Bank of Denver v. First Central Bank of Denver, 511 U.S. 164 (1994).

42. 15 U.S.C. § $78 \mathrm{t}(\mathrm{e})$.

43. In reEnron Corporation Securities, Derivative\& ERISA Litigation, 2002 WL 31854963 (S.D. Tex.).

44. Pub. L. N o. 105-353, 112 Stat. 3227 (1998).

45. Pub. L. N o. 107-204, § 304 (July 30, 2002).

Published by the Cato Institute, Policy Analysis is a regular series evaluating government policies and offering proposals for reform. N othing in Policy Analysis should be construed as necessarily reflecting the views of the Cato Institute or as an attempt to aid or hinder the passage of any bill before congress. Contact the Cato Institute for reprint permission. Additional copies of Policy Analysis are $\$ 6.00$ each ( $\$ 3.00$ each for five or more). To order, or for a complete listing of available studies, write the Cato Institute, 1000 Massachusetts Ave., N.W., Washington, D.C. 20001, call toll free 1-800-767-1241 (noon - 9 p.m. eastern time), fax (202) 842-3490, or visit our website at www.cato.org. 